\title{
Mesa, S. (2019) Silencio administrativo. La pobreza en el laberinto burocrático. Barcelona: Anagrama.
}

\author{
Rafael Enrique Valenzuela Mendoza \\ Universidad Autónoma de Ciudad Juárez, México \\ rafael.valenzuela1@gmail.com
}

Este libro relata el esfuerzo de Carmen, una ciudadana de Andalucía, España, por acceder al derecho a una renta mínima, es decir, a una ayuda social de ingreso mensual por espacio de un ańo para personas en extrema pobreza. En el caso que describe el libro, el servidor público intermediario entre el gobierno y Carmen, son los trabajadores sociales en Andalucía, Espańa. Una obra denominada por la autora como crónica, en realidad representa una investigación mostrada desde una narrativa asequible y entendible, que pone de manifiesto los estereotipos que existen en la sociedad acerca de los beneficios y programas sociales a los más desfavorecidos en la escala social económica.

La autora da voz a Carmen, una indigente a la que conoce Beatriz y a quien decide ayudarle. El silencio administrativo que reconstruye la autora refiere a la falta de respuesta de la administración pública, a la insensibilidad mostrada por el servidor público que desconoce la compleja espiral de problemas que rodean a la gente que vive en pobreza extrema.

La solicitud de documentos que no poseen, comprobantes de residencia, citas en fechas lejanas, exigencia de requisitos de difícil cumplimiento, hace que los más pobres no accedan con facilidad, o simplemente no puedan concluir un trámite iniciado, debido a que la pobreza no es un asunto estrictamente económico, sino de violencia social como la discriminación y el arraigo de estereotipos expresados en afirmaciones como que es pobre el que quiere, o como que las ayudas que ofrece el gobierno son vastas y están disponibles para todos los que están en condición de pobreza, o bien, que muchos simplemente no acceden a las ayudas del gobierno porque no quieren.

Estos estereotipos conducen la autora a citar a la filósofa española Adela Cortina, de quien retoma el concepto aporofobia, que significa el odio hacia los pobres, para explicar que la pobreza no es la falta de ingresos, sino una cadena de problemas que deben resolverse en forma integral. La decisión de Beatriz de ayudar a Carmen, se traduce en una acción que le permite ver lo difícil que es obtener ayuda gubernamental. 
La investigación presentada sigue un método de acción participativa, en el cual la autora acompańa y vive de manera personal, las dificultades que debe pasar una persona en situación de calle y que vive de pedir apoyos en la vía pública, de manera diaria a quienes son transeúntes en las calles que ocupa para esa actividad.

La vida de Carmen es el reflejo de lo que acontece en un mundo desconocido por muchos servidores públicos o ciudadanos que tienen una vida normal, estable y que obtienen lo básico para vivir. Un problema de pobreza esconde un conjunto de situaciones de riesgo presentes, y daños ocurridos en el pasado, como ser víctima de trata de personas, explotación laboral, adicción a las drogas, falta de salubridad, abuso y violencia en sus distintas modalidades, discriminación de ciudadanos y del propio gobierno al brindar ayudas, entre otros.

Carmen resulta ser víctima del silencio administrativo y de servidores públicos que la revictimizan por pedir ayuda a la que tiene derecho. El perfil que retrata el libro del servidor público de ventanilla, resulta ser de difícil comprensión. Un servidor público que no brinda información completa o que omite información o datos valiosos que ayuden a obtener la ayuda, que juzga a la persona solicitante del apoyo por la falta de documentos y su vida de calle, que administra una partida de ayuda en caso de emergencias, sin fondos, ni previsiones del ejercicio presupuestal.

La falta de repuesta configura el silencio administrativo, que lleva a Beatriz a indagar que ocurre y se introduce a un laberinto burocrático. En el encuentran Carmen y Beatriz que todo queda a cargo del solicitante, y ante cualquier cambio de la situación de precariedad que vive Carmen, de no notificarlo a la administración de la ciudad, el trámite se archiva. Desde una posición de poder, el laberinto burocrático exige demandas puntuales al solicitante del apoyo social, bajo el riesgo de archivar el expediente sino se cumplen. Tales demandas están circunscritas al cambio de domicilio, la falta de asistencia a indagar sobre su expediente, si obtuvo algún ingreso adicional, todo ello de notificarse, alargaría meses el trámite.

Cuando se creó el programa de rentas mínimas, Beatriz recordó la felicidad que le invadió. No obstante, al vivir en carne propia el proceso de obtención de tal ayuda para Carmen, comprendió el programa con base en la experiencia y los datos que le proporcionó el realizar el trámite. Beatriz reflexiona, ¿Cómo puede presumir el gobierno que el ingreso o renta mínima que está por debajo de las necesidades de las familias vaya a tener algún impacto, si el presupuesto para cubrir a 42.000 familias la renta mínima no es consistente con los más de 600.000 personas que están 
en situación de pobreza extrema en Andalucía?

Estas reflexiones de Beatriz ponen en el centro del debate si los apoyos que ofrece el gobierno sirven para salir de la pobreza a las personas que deben esperar alrededor de siete meses. Tales ayudas tienen duración de un ańo, y no es suficiente para salir de una emergencia o simplemente para sobrevivir.

Si bien se comentó líneas arriba que, a lo largo de trece capítulos, una nota inicial y un epilogo, existió una metodología de acción participativa, Beatriz no es la autora, sino que forma parte de un colectivo que logró construir acción colectiva en favor de Carmen para obtener la ayuda. La gestión duró siete meses de lucha cotidiana ante la autoridad, colectivo que pudo vencer de manera pírrica al laberinto burocrático, más no al silencio administrativo que aún prevalece vigente, jugando en contra de los más pobres.

Este libro recurre a datos, a una historia verificable y a la descripción de un fenómeno social que parece obviar el ciudadano promedio: que los presupuestos para combatir la pobreza son ineficientes y muestran la débil capacidad institucional del gobierno para otorgar un mínimo de libertad económica a lo excluidos sociales. La pobreza no es un problema, es una red de problemas que operan en un sistema que no los resuelve, ni ataja, solo los administra. De nuevo la complejidad aparece como una mirada comprensiva que ayuda a conectar multicausalidad a un fenómeno poco comprendido, tanto en lo social, lo académico, como en lo económico. 